Original Research Paper

\title{
Effect of Sticky Trap Color and Height on the Capture of Adult Oriental Fruit Fly, Bactrocera dorsalis (Hendel) (Diptera: Tephritidae) on Chili Pepper
}

\author{
Ahwiyah Ekawaty Said, Fatahuddin, Asman and Andi Nasruddin \\ Department of Plant Pests and Diseases, Faculty of Agriculture, \\ Hasanuddin University Makassar, South Sulawesi, Indonesia 90245, Indonesia
}

\author{
Article history \\ Received: 21-10-2016 \\ Revised: $21-12-2016$ \\ Accepted: 29-12-2016 \\ Corresponding Author: \\ Andi Nasruddin \\ Department of Plant Pests and \\ Diseases, Faculty of \\ Agriculture, Hasanuddin \\ University Makassar, South \\ Sulawesi, Indonesia 90245, \\ Indonesia \\ Email: andinasruddin@yahoo.com
}

\begin{abstract}
Oriental fruit fly, Bactrocera dorsalis, (Hendel) (Diptera: Tephritidae) is a destructive pest to many major crops, including chili pepper (Capsicum frutescens L). The insect can cause yield loss up to $100 \%$ in the absence of any control measures. One control tactic commonly used by pepper growers to control the fruit fly is sticky trap to capture the adults. The purpose of the current study was to elucidate the effect of trap color and height on the fly capture. The results showed that yellow trap was consistently the most attractive trap amongst the other trap colors tested with an overall average of 62.6 adults per trap during the study. The second most attractive traps were white and green traps with overall averages of 45.2 and 40 adults per trap, respectively. The attractiveness levels of the red and blue traps were comparable each other with overall averages of 29.4 and 25.4 adults per trap, respectively. The least attractive trap was black trap with an overall average of 17.1 adults per trap, which was significantly lower than the other trap colors. In addition, traps set up at 25 and $50 \mathrm{~cm}$ above the ground captured significantly more adults (187.8 and 171.9 per trap, respectively) compared to those set up at 75 and $100 \mathrm{~cm}$ above the ground (60.8 and 37.1 per trap, respectively). When the combination of the color and height of the traps were analyzed, the yellow, white and green traps set up at 25 and $50 \mathrm{~cm}$ above the ground caught the highest numbers of adult fruit flies and they were not significantly different each other. Thus, these combinations should be recommended to the pepper growers to control the insect in their plantations.
\end{abstract}

Keywords: Trap Color, Trap Height, Bactrocera dorsalis

\section{Introduction}

Oriental fruit fly, Bactrocera dorsalis (Hendel) (Diptera: Tephritidae) is one of the most important limiting factors of pepper production in Indonesia, including South Sulawesi Province (Widanengsih, 2014). The fruit fly has caused serious damages on pepper throughout the province and can cause yield loss up to $100 \%$ when no control measures are applied (Nasruddin, unpublished data).

Infested pepper fruits showed black spots of ovipositor marks when the female insects lay eggs by inserting them into the fruit skin. The eggs hatch 2-3 days later and the newly formed larvae feed and develop inside of the fruits. At the last larval instar (third instar), the larvae crawl out of the fruits and drop themselves to the ground before they pupate in the soil (Mau and Matin, 2007; Widanengsih, 2014). At this stage, the fruits have already been damaged, prematurely dropped off the plants and unmarketable. The pupal stadium lasts for about 10 days before the adults emerge from the ground and fly around to find protein-laden foods before they mate. Protein diets are very important for the fly's ovarian development and egg production (Vargas et al., 2015). In the tropics, the fruit fly's life cycle is about 25 days (Drew and Romig, 2013).

Pepper growers rely heavily on insecticide use for the control of the insect with application frequencies of 2-3 times per week. The intensive use of insecticides can trigger resistance development in the insect against the insecticides. Besides that, it can also affect non-target organisms and even the consumers' health (Pedigo, 1996). 
Thus, safer alternative control measures must be employed such as the use of sticky color trap to catch fruit fly adults. Sticky substance amended with protein hydrolysate or male annihilation substances such methyl eugenol as lure (Roessler, 1989) is widely used in trapping the fruit fly. Enzymatic protein hydrolysate baits were first used in Hawaii for control of B. dorsalis (Steiner, 1952).

A fruit fly species may have different preferences of trap color. Oriental fruit fly is most attracted to green, yellow and orange colors in a laboratory experiment (Wu et al., 2015); while the insect is most attracted to green and orange and black traps when the traps were set up in guava and mango fields, respectively (Ravikumar and Viraktamath, 2007). Besides that, trap height from the ground can also affect the preference of particular species. For example, Rhagoletis pomonella prefers traps placed approximately $2.1 \mathrm{~m}$ above the ground within the apple tree canopy (Reissig, 1975; Drummond et al., 1984), while $R$. mendax are most attracted by the traps placed within the top of highbush blueberry plants, Vaccinium corymbosum L., when the bushes are 1.5 to $2.0 \mathrm{~m}$ high (Liburd et al., 2000; Teixeira and Polavarapu, 2001). Currently, no information is available about trap color and height that are suitable to catch $B$. dorsalis in pepper plantation. Therefore, the purpose of the current study was to determine the best combination of trap color and height for catching the fruit fly adults.

\section{Materials and Methods}

\section{Study Site}

The study was conducted in the Teaching Farm, Faculty of Agriculture, Hasanuddin University, Makassar, South Sulawesi, Indonesia ( $5^{\circ} 07^{\prime} \mathrm{S}$ and $119^{\circ}$ $28^{\prime} \mathrm{E}$ ) at an altitude of $13 \mathrm{~m}$, from December 1, 2015 to September 30, 2016. The area experiences rainy seasons from October/November to April/May with an average annual precipitation of $2875 \mathrm{~mm}$ and mean annual temperature of $27.4^{\circ} \mathrm{C}$ (BPS, 2015).

\section{Trap Color}

To determine the effect of trap colors on the adult fly capture, 3-wk old seedlings of chili pepper (Capsicum frutescens L.) cv. Bhaskara were transplanted on 15 December 2015. Planting space used was $1 \mathrm{~m}$ between rows and $75 \mathrm{~cm}$ within the rows. The plants were raised by following the local cultivation practices. Treatments consisted of six trap colors: Red, yellow, black, white, blue and green. The traps were made of plastic sheets $(20 \times 30 \mathrm{~cm})$ with different colors supported by a wooden stake at a height of $50 \mathrm{~cm}$ above the ground. The plastic sheets were individually covered with a plastic bag and then the plastic bags were painted with a sticky substance amended with protein hydrolysate as a lure for the fruit fly. When the plants started blooming (6 weeks after transplanting), the traps were placed in the chili pepper field following a complete randomized block design with four replicates. The distance between traps was $15 \mathrm{~m}$. The number of flies caught per trap were recorded five times every seven days by removing the plastic bags and then bringing them back to the Laboratory of Insect in Relation to Plant Disease, Faculty of Agriculture, Hasanuddin University for identification and count under a dissecting microscope.

\section{Trap Height}

The effect of trap height from the ground on the adult fly capture was determined by establishing a chili pepper (C. frutescens) cv. Bhaskara plantation on 9 March 2016 by following the procedures described in the trap color experiment above. Treatments consisted of four trap heights: 25, 50, 75 and $100 \mathrm{~cm}$ above the ground. The traps were made of yellow plastic sheets $(20 \times 30 \mathrm{~cm})$ supported with wooden stakes. The plastic sheets were individually covered with plastic bags and then the plastic bags were painted with a sticky substance amended with protein hydrolysate as a lure for the fruit fly. When the plants started blooming (6 weeks after transplanting), the traps were placed in the chili pepper field following a complete randomized block design with four replicates. The distance between traps was $15 \mathrm{~m}$. The number of flies caught per trap were recorded every seven days by removing the plastic bags and then bringing them back to our laboratory for identification and count under a dissecting microscope.

\section{Trap Color and Height Combination}

Three weeks old seedlings of chili pepper cv. Bhaskara were planted on June 1, 2016. Planting space used was $100 \mathrm{~cm}$ between rows and $75 \mathrm{~cm}$ within a row. Plant maintenance was performed by following the locally recommended practices. Treatments consisted of six trap colors: Red, yellow, black, white, blue and green; and four trap heights: $25,50,75$ and $100 \mathrm{~cm}$ above the ground. Thus, there were 24 treatment combinations tested in this experiment and they were arranged in a complete randomized block design with four replicates. The traps were made of plastic sheets $(20 \times 30 \mathrm{~cm})$ supported with wooden stakes. The plastic sheets were individually covered with plastic bags and then the plastic bags were painted with a sticky substance amended with protein hydrolysate as a lure for the fruit fly. When the plants started blooming ( 6 weeks after transplanting), the traps were placed in the chili pepper field. The distance between traps was $15 \mathrm{~m}$. The numbers of flies caught per trap were recorded every seven days by removing the plastic bags and then bringing them back to our laboratory for identification and count under a dissecting microscope.

Adult fruit fly counts for each experiment were transformed using $\log (\mathrm{x}+1)$ before they were subjected 
to an analysis of variance (ANOVA). When a significant difference was detected, the treatment means were separated using a Duncan's multiple range test $(\mathrm{P} \leq 0.05)$.

\section{Results}

\section{Experiment 1: Effect of Trap Color on Fruit Fly Capture}

There was a significant difference in the number of adults of $B$. dorsalis caught amongst the trap color treatments (Table 1). Yellow trap consistently caught significantly more adult flies compared to the other trap colors tested. The overall mean of catch for the yellow trap was 62.2 flies per trap. This was followed by white and green traps with the overall mean catches of 45.3 and 40 individuals per trap, respectively. While red and blue traps were not significantly different each other with the overall mean catches of 29.4 and 25.4 flies per trap, respectively. Black trap was the least attractive to $B$. dorsalis adults with an average catch of 17.1 per trap, compared to the other treatments.

\section{Experiment 2: Effect of Trap Height on Fruit Fly Capture}

There was a significant difference in the numbers of adults of $B$. dorsalis caught in yellow traps with different heights (Table 2). Traps set up at 25 and $50 \mathrm{~cm}$ above the ground caught an average of 187.8 and 171.9 flies, respectively. These numbers were not significantly different each other but they were significantly bigger than those caught in the traps set up at 75 and $100 \mathrm{~cm}$ above the ground which were 60.8 and 37.1 flies, respectively.

\section{Experiment 3: Effect of Trap Color and Height Combination on Fruit Fly Capture}

Statistical analysis showed a significant difference in catch numbers amongst color treatments or amongst height treatments but no interaction between the two factors existed (Fig. 1). These data confirmed the previous results (experiment 1 and 2) that yellow, white and green traps placed at 25 and $50 \mathrm{~cm}$ above the ground were the most attractive to $B$. dorsalis.

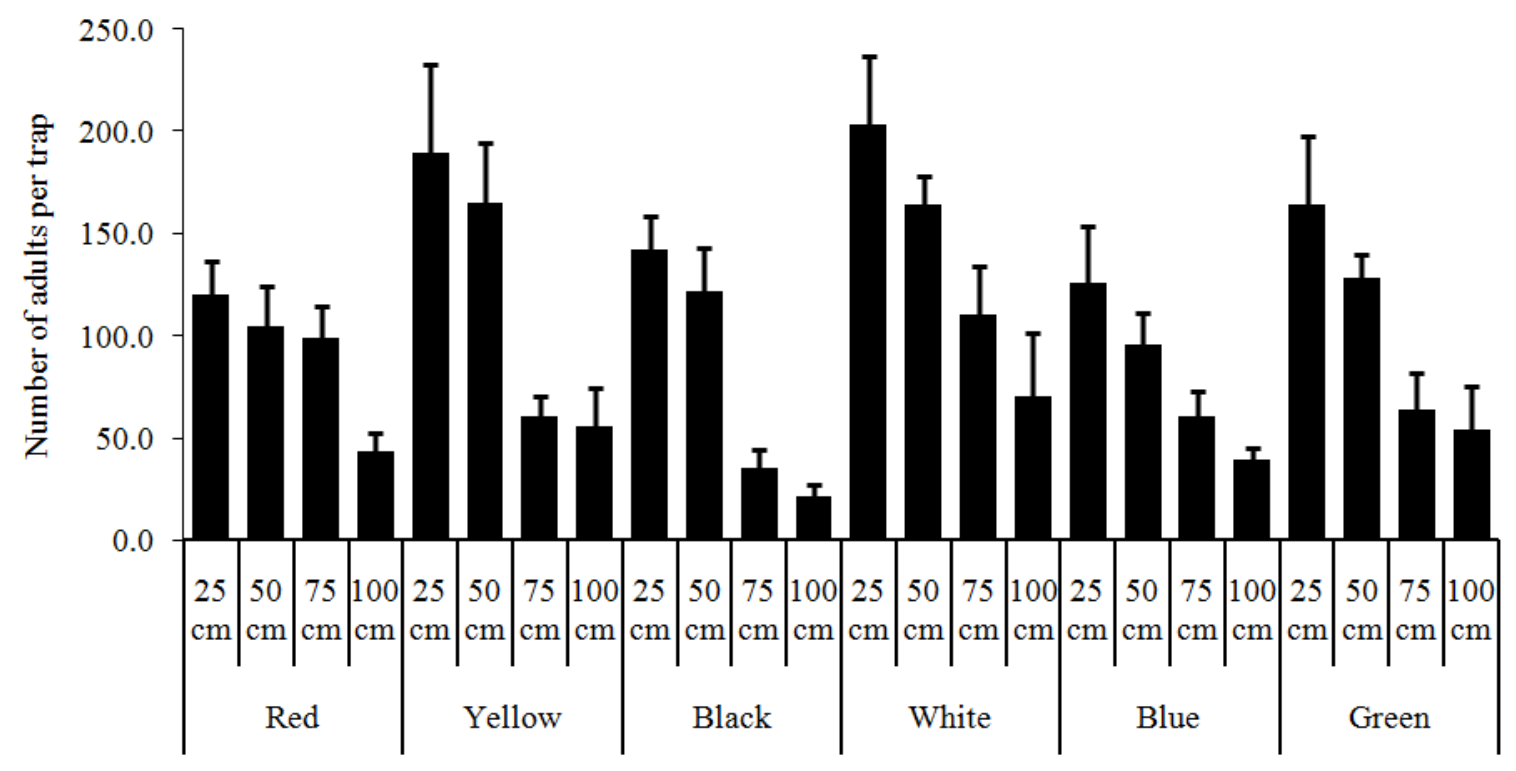

Fig. 1. Mean numbers of adults of $B$. dorsalis captured per trap using different trap colors and heights above ground for five weekly counts. Bars represent standard errors of sample means

Table 1 . Numbers of fruit fly adults $(B$. dorsalis) captured per trap by using different trap colors during five weekly counts

\begin{tabular}{|c|c|c|c|c|c|c|}
\hline \multirow[b]{2}{*}{ Trap color } & \multicolumn{6}{|c|}{ Number of adults per trap $(\mathrm{x} \pm \mathrm{SE})$} \\
\hline & $3 \mathrm{Feb}$ & $10 \mathrm{Feb}$ & $17 \mathrm{Feb}$ & $24 \mathrm{Feb}$ & $2 \mathrm{Mar}$ & Overall mean \\
\hline Red & $31.0 \pm 12 \mathrm{a}$ & $26.8 \pm 5.6 \mathrm{~b}$ & $38.7 \pm 8.2 b c$ & $12.8 \pm 4.4 \mathrm{c}$ & $37.8 \pm 5.6 \mathrm{c}$ & 29.4 \\
\hline Yellow & $36.0 \pm 11 \mathrm{a}$ & $52.3 \pm 2.7 \mathrm{a}$ & $72.5 \pm 9.4 \mathrm{a}$ & $65.8 \pm 8.1 \mathrm{a}$ & $86.3 \pm 14.9 \mathrm{a}$ & 62.6 \\
\hline Black & $12.3 \pm 5 c$ & $20.8 \pm 8.4 \mathrm{c}$ & $23.0 \pm 7.2 \mathrm{c}$ & $12.4 \pm 9.4 \mathrm{c}$ & $21.8 \pm 4.4 \mathrm{~d}$ & 17.1 \\
\hline White & $36.3 \pm 10 \mathrm{a}$ & $40.3 \pm 4.9 \mathrm{~b}$ & $54.8 \pm 9.1 b$ & $45.0 \pm 8.6 \mathrm{~b}$ & $49.8 \pm 13.6 b$ & 45.3 \\
\hline Blue & $29.8 \pm 11 \mathrm{a}$ & $28.8 \pm 6.1 \mathrm{~b}$ & $36.3 \pm 9.7 b c$ & $14.8 \pm 5.1 \mathrm{c}$ & $16.5 \pm 2.8 \mathrm{~d}$ & 25.4 \\
\hline Green & $29 \pm 13 a$ & $31.5 \pm 7.2 \mathrm{~b}$ & $55.8 \pm 8.1 \mathrm{~b}$ & $43.3 \pm 9.2 b$ & $40.3 \pm 2.9 b c$ & 40.0 \\
\hline
\end{tabular}

Numbers in a column, followed by the same letter, are not significantly different by Duncan's multiple range test (P $\leq 0.05)$ 
Table 2. Numbers of fruit fly adults (B. dorsalis) captured per trap by using yellow traps placed at different heights above the ground during five weekly counts

\begin{tabular}{|c|c|c|c|c|c|c|}
\hline \multirow[b]{2}{*}{ Height $(\mathrm{cm})$} & \multicolumn{6}{|c|}{ Number of adults per trap $(\mathrm{x} \pm \mathrm{SE})$} \\
\hline & 4 Aug & $11 \mathrm{Aug}$ & $18 \mathrm{Aug}$ & $25 \mathrm{Aug}$ & $1 \mathrm{Sep}$ & Overall mean \\
\hline 25 & $145.3 \pm 12 \mathrm{a}$ & $144.3 \pm 9.6 \mathrm{a}$ & $223.4 \pm 8.5 \mathrm{a}$ & $180.8 \pm 7.4 \mathrm{a}$ & $245.6 \pm 27.6 \mathrm{a}$ & 187.8 \\
\hline 50 & $148.6 \pm 11 \mathrm{a}$ & $131.4 \pm 8.9 \mathrm{a}$ & $205.5 \pm 11.4 \mathrm{a}$ & $165.8 \pm 8.3 \mathrm{a}$ & $208.3 \pm 11.9 \mathrm{a}$ & 171.9 \\
\hline 75 & $45.3 \pm 5 c$ & $97.8 \pm 8.3 b$ & $55.0 \pm 7.5 b$ & $41.0 \pm 9.7 b$ & $64.8 \pm 8.4 b$ & 60.8 \\
\hline 100 & $88.3 \pm 10 b$ & $12.6 \pm 5.9 \mathrm{c}$ & $37.8 \pm 9.5 b$ & $26.6 \pm 9.6 b$ & $19.89 \pm 4.6 \mathrm{c}$ & 37.1 \\
\hline
\end{tabular}

Numbers in a column, followed by the same letter, are not significantly different by Duncan's multiple range test (P $\leq 0.05)$

\section{Discussion}

Sticky traps are commonly used to suppress pests' populations or to monitor their presence in a particular place or region (IAEA, 2003). Control tactic of using sticky trap is an effective way of reducing adult population in a safe manner and can be incorporated into an integrated pest management strategy. Sticky trap can also be used for monitoring the presence and population level of a particular insect species in a certain place or region and time.

Oriental fruit fly populations were relatively high during the trap trials. The fruit fly adults most likely came from mango trees around the trial site. Our results showed that yellow, white and green were the most attractive trap colors to $B$. dorsalis and caught significantly more flies than did the red, blue and black traps. Whereas Ravikumar and Viraktamath (2007) reported that $B$. dorsalis was caught the most in green and orange traps. Traps placed at 25 and $50 \mathrm{~cm}$ above the ground for all colors caught significantly more adults than did those placed at 75 and $100 \mathrm{~cm}$ above the ground. This was in agreement with Atakan and Canhilal (2004) reported that as the height of trap increased, the lower numbers of leafhoppers and whiteflies were caught in those traps. Newly emerging fruit fly adults from the ground are urgently in need of protein diets before they mate. Thus, the traps set up at 25 and $50 \mathrm{~cm}$ above the ground seemed to be easier for them to reach the protein hydrolysate bait than those placed 75 and $100 \mathrm{~cm}$ above the ground. However, Rhagoletis pomonella prefers traps placed approximately $2.1 \mathrm{~m}$ above the ground within the apple tree canopy (Reissig, 1975; Drummond et al., 1984) and $R$. mendax is most attracted to traps placed within the top of highbush blueberry plants, Vaccinium corymbosum L., when the bushes are 1.5 to $2.0 \mathrm{~m}$ high (Liburd et al., 2000; Teixeira and Polavarapu, 2001). Thus, the current study and the previous study results suggested that the insect's preference to trap color and height varied based on fruit fly species, plant phenology and the environment.

\section{Conclusion}

This study demonstrated that trap color and height significantly affected the trap effectiveness in capturing B. dorsalis. Yellow, white and green traps placed 25 and
$50 \mathrm{~cm}$ above the ground were the most effective amongst the traps tested. These treatment combinations should be used for the control and monitoring the oriental fruit fly using traps in chili pepper plantation in order to control the insect. To the best of our knowledge, this is the first report on the oriental fruit fly preference of trap color and height in chili pepper plantation.

\section{Acknowledgement}

We thank Muhammad Said Baco and Andi Dirham Nasruddin, Muh Ridwan and Muh Mewar for technical assistance. This work was financially supported by the Ministry of Research, Technology and Higher Education, Republic of Indonesia under the World Class University (WCU) Research Scheme 2016, administered by the Institute of Research and Community Services (LPPM) Hasanuddin University, Makassar, Indonesia.

\section{Author's Contributions}

Ahwiyah Ekawaty Said: Designed research plan and collected data.

Fatahuddin: Designed research plan and performed data analysis.

Asman: Designed research plan and organized data collection.

Andi Nasruddin: Coordinated research activities, designed research plan and prepared the manuscript.

\section{Ethics}

This article is an original research paper and contains unpublished data, except the abstract that is available in the electronic repository system, Hasanuddin University (http://repository.unhas.ac.id/) as required by the institution. The corresponding author confirms that no ethical issues will occur due to the publication of the manuscript.

\section{References}

Atakan, E. and R. Canhilal, 2004. Evaluation of yellow sticky traps at various heights for monitoring cotton insect pests. J. Agric. Urban Entomol., 21: 15-23.

BPS, 2015. South Sulawesi in Figures. 1st Edn., Badan Pusat Statistik, pp: 265. 
Drew R.A.I. and M.C. Romig, 2013. Tropical Fruit Flies (Tephritidae Dacinae) of South-East Asia: Indomalaya to North-West Australasia. 1st Edn., CAB International, Wallingford, ISBN-10: 1780640358, pp: 653.

Drummond, F., E. Groden and R.J. Prokopy, 1984. Comparative efficacy and optimal positioning of traps for monitoring apple maggot flies (Diptera: Tephritidae). Environ. Entomol., 13: 232-235. DOI: $10.1093 /$ ee/13.1.232 232-235

IAEA, 2003. Trapping guidelines for area wide fruit fly programs. International Atomic Energy Agency, IAIE.

Liburd, O.E., S. Polavarapu, S.R. Alm and R.A. Casagrande, 2000. Effect of trap size, placement and age on captures of blueberry maggot flies (Diptera: Tephritidae). J. Econ. Entomol. 93: 1452-1458. PMID: 11057717

Mau, F.L. and J.L. Matin, 2007. Bactrocera dorsalis (Hendel). Crop Knowledge Master.

Pedigo, L.P., 1996. Entomology and Pest Management. 2nd Edn., Prentice Hall, Upper Saddle River, ISBN-10: 0133735311, pp: 679.

Ravikumar, P. and S. Viraktamath, 2007. Attraction of female fruit flies to different protein food baits in guava and mango orchards. Karnataka J. Agric. Sci., 20: $745-748$.

Reissig, W.H., 1975. Performance of apple maggot traps in various apple tree canopy positions. J. Econ. Entomol., 68: 534-538. DOI: 10.1093/jee/68.4.534
Roessler, Y., 1989. Insecticidal Bait and Cover Spray. In: Fruit Flies: Their Biology, Natural Enemies and Control, Robinson, A.S. and G. Hooper (Eds.), Elsevier, Amsterdam, ISBN-10: 0444427635, pp: 329-335.

Steiner, L.F., 1952. Methyl eugenol as an attractant for oriental fruit fly. J. Econ. Entomol., 45: 241-248. DOI: $10.1093 /$ jee/45.2.241

Teixeira, L.A.F. and S. Polavarapu, 2001. Effect of sex, reproductive maturity stage and trap placement, on attraction of the blueberry maggot fly (Diptera: Tephritidae) to sphere and Pherocon AM traps. Florida Entomol., 84: 363-369. DOI: 10.2307/3496493

Vargas, R.I., J.C. Piñero and L. Leblanc, 2015. An overview of pest species of Bactrocera fruit flies (Diptera: Tephritidae) and the integration of biopesticides with other biological approaches for their management with a focus on the pacific region. Insects, 6: 297-318. DOI: 10.3390/insects6020297

Widanengsih, E., 2014. Lalat Buah (Bactrocera spp.) pada Tanaman Cabai (Capsicum annum L.). Satasiun Balai Karantina Kelas II, Tanjung Balai Karimun.

Wu, W.Y., Y.P. Chen and E.C. Yang, 2015. Spectral sensitivity and color preference of the oriental fruit fly, Bactrocera dorsalis (Diptera: Tephritidae). Department of Entomology, National Chung Hsing University, Taichung, Taiwan. 